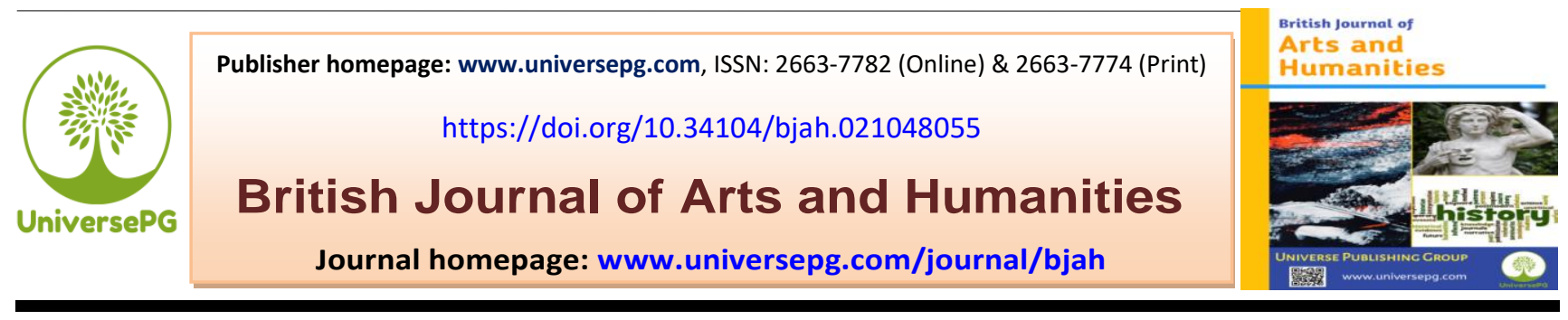

\title{
Customer's Satisfaction toward Robi Axiata Limited: Study on Rajshahi University Area
}

\author{
Shalehar Khatun ${ }^{1}$ and Md. Rubel Hossain ${ }^{2 *}$ \\ ${ }^{1 \& 2}$ Department of Library and Information Science, Khwaja Yunus Ali University, Sirajgonj, Bangladesh. \\ *Correspondence: rubelru91@gmail.com (Md. Rubel Hossain, Lecturer, Department of Library and Information \\ Science, Khwaja Yunus Ali University, Sirajgonj, Bangladesh).
}

\begin{abstract}
The beginning of the telecommunication business has been appealing not on time in Bangladesh when to compare Asian countries. The mobile telecommunication of serving is repetition on a yearly basis over the last two or three years. Now in our country four mobile phone operators, one is Robi. Most of the companies are offering diverse innovative packages and offer charge added services for satisfying the customer's needs \&demands. This research is the main objective to find out Customer's satisfaction with Robi Axiata Limited in Rajshahi University area. There are different ways which have an effect on the performance. The aim of this paper is to search crucial issues which regularly control the more level of performance of mobile users in the Rajshahi University area. Network of coverage, quality of the network, quality of internet, taxes, customer services, value-added services, payment system; encouraging offers are the utmost valuable issues that feelings customer fulfillment. Robi carries their work till now because of their different 4.5 packages.
\end{abstract}

Keywords: Telecommunication, Customer satisfaction, Mobile operators, Robi Axiata, and Network quality.

\section{INTRODUCTION:}

Majority of the person of Bangladesh are dreaming on digital. The quick improvement of telecommunication network quality to give better service for national development which fulfillment the mission and vision of digital Bangladesh in the $21^{\text {st }}$ century. The last era has carried out the first tendency of the accurately mobile generation which is made every where mobile phones, short messaging service (SMS), and transferrable electronic aides (Jony et al., 2019). To develop of our economy telecommunication commercial sector is the flourishing sectors within ICT ministry.

From of the four notable mobile phone operators Robi is to big contribution to our economy. The main objective of this paper is to find out Customer's satisfaction towards Robi Axiata Limited in the Rajshahi University area. This paper is constructed from primary and secondary data. Mobile operators of Robi are the source of primary data in the region of Rajshahi university area. The quantity of 60 customers was surveyed over the critical judgement of sampling method to this questionnaire.

\section{Literature Review}

The outcomes of the papers were the mobile operators placed significant position to the matter of user support. The right link between mobile client satisfaction and client support (Shuvro et al., 2020). When client to support becomes broader the leaning of pleasure becomes stronger. Saha et al. (2016), a study reveals that customer satisfactions are mostly figured on price, network, and different packaging offer internet facility. If above quality is suitable then the majority of the user are satisfied. Abraham Pizam and Taylor Ellis, (1999) in generosity his enterprises originate that if rightly planned, well administered and examined, the way of looking after user satisfaction might be helpful to any kindness 
enterprise and to ready the alterative amongst present average goods and an outstanding, useful product.

Uddin and Akhter, (2012), his study on user gratification in the mobile phone package in Bangladesh, he finds out reasonable price is direct impact on to the customer but no significant impact of facility quality for customer. So, the reveal is clear that service quality is not satisfactory in compare to take cash from the customer. Qi and Shu, (2007) in his study to point out clientele contentmentequal of mobile telecommunication zone. The competition among mobile operators becoming raising day by day he shows in his research. They revealed that every mobile operator company try to emphasis user satisfaction with services and also improve how to develop future customer services in a legal competition way (Gereziher and Shiferaw, 2020; Hossain et al., 2019).

Al Jamil et al. (2015) find out his study is that customer different brand converting focus on tariff packages, internet speed, or other advertising works. Call rate and tariff plan is more significant role for switching their mobile company of a customer. Smith et al. (1999) in his research tries to reveal a model of customer satisfaction and with services its failure and how to recover it. In his research framework he shows service letdown and way to recover through customer evaluation. Also found that speedy recovery, damage from the failure and positive impact of customer perception. Finally, they draw plans to recovery this failure and effective customer's service.

Kim et al. (2004) he argues that customer satisfaction is mainly based on different core services which are the quality services, value added services. This type of quality services to raise the impact of customer loyalty. This paper found that quality service is the crucial reasons to enhance customer fulfillment with the loyalty of the users. Chen, (2008) in his paper to conclude that if the company or operators to raise their future customer satisfaction definitely no compromise of providing quality services. User satisfaction or loyalty mainly depends on assurance to provide better service offer for the clientele.

Rahman, (2014), a study to find out that, customer contentment is important for present market value.
Customer satisfaction depends on service quality, reliability, better network coverage, packaging offer or low-price call rate.

\section{Objectives of the Study}

1) Getting knowledge about complete satisfaction level among users in Rajshahi University area.

2) Categorize the customer's product preference among users in Rajshahi University area.

3) Getting knowledge on recent market share among users in Rajshahi.

\section{METHODOLOGY:}

The variety of applicable sources of data submission of appropriate data collection technique and with the using of right statistical test and techniques for analyzing the collected data, etc. are concerning methodology of the study.

\section{Problem statement}

Mobile phone industry is the recent era or dynamic segment in Bangladesh. In Bangladesh so many mobile operators with huge competition. So, user has lots of option to select their brands. Different reasons are for affecting customer satisfaction behind this. Mostly students and other common people are the significant for the mobile operator company. So their satisfaction and dissatisfaction is the important segment for market value. If the customers are dissatisfied, they will massively lose their market. My goal to determine user satisfaction level of Robi mobile operating company.

\section{Data collection method}

Primary Data - Both primary and secondary research will be constructed on this research. For Primary research, we will do study on among users in Rajshahi University area.

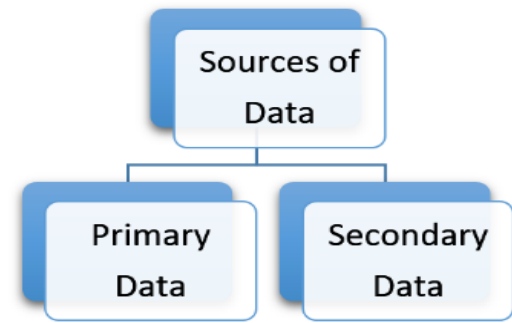

Secondary Data - I search and try to read related literature on different article along with newspapers on employee and customer fulfillment also their relation by accumulating the information. 
Population and the amount sample size - The full amount users are comparably high. So, it is not too sure likely to effort on this large number of populations. As I working on customer satisfaction inside the Rajshahi university area, so trying to collect actual information from this area. I consider users who are students. I take 60 customers as my sampling.

\section{ANALYSIS AND FINDINGS:}

The collected data has analyzed to fulfill proposed objective of this study. Now the analyzed data will put into graph and interpret for better understanding.

\section{Analysis}

According to sample it is originate that Robi has $35 \%$ markets share among users in Rajshahi University area.

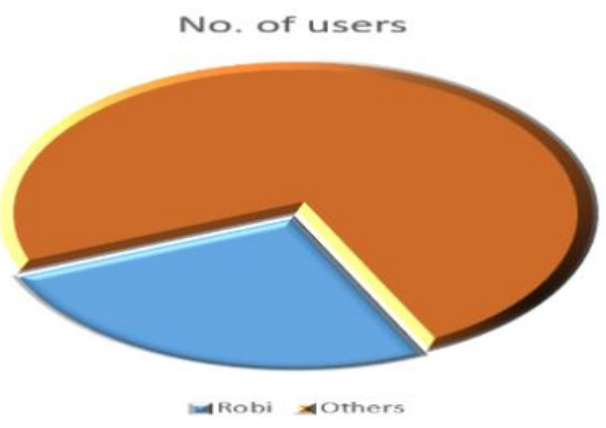

\section{Brand preference}

Only 35\% Robi users prefer to their respective brands

\begin{tabular}{|c|c|c|}
\hline & Robi & Total \\
\hline Users & 21 & 60 \\
\hline Percentage & $35 \%$ & $100 \%$ \\
\hline
\end{tabular}

Customer's satisfaction towards Robi Axiata Limited (A Study on Rajshahi University Area)

Table 1: On the basis of call rate

\begin{tabular}{|l|c|c|c|c|c|c|}
\hline & $\begin{array}{c}\text { Not } \\
\text { Satisfied }\end{array}$ & Dissatisfied & $\begin{array}{c}\text { Neither Satisfied } \\
\text { nor Dissatisfied }\end{array}$ & Satisfied & $\begin{array}{c}\text { Highly } \\
\text { satisfied }\end{array}$ & Total \\
\hline No. of users & 0 & 0 & 0 & 20 & 1 & 21 \\
\hline $\begin{array}{l}\text { Percentage } \\
(\%)\end{array}$ & $0 \%$ & $0 \%$ & $0 \%$ & $95.24 \%$ & $4.76 \%$ & $100 \%$ \\
\hline
\end{tabular}

Table 2: On the basis of Bonus (Special offers)

\begin{tabular}{|l|c|c|c|c|c|c|}
\hline & Not Satisfied & Dissatisfied & $\begin{array}{c}\text { Neither Satisfied } \\
\text { nor Dissatisfied }\end{array}$ & Satisfied & $\begin{array}{c}\text { Highly } \\
\text { satisfied }\end{array}$ & Total \\
\hline No. of users & 2 & 0 & 14 & 5 & 0 & 21 \\
\hline $\begin{array}{l}\text { Percentage } \\
(\%)\end{array}$ & $9.52 \%$ & $0 \%$ & $66.67 \%$ & $23.81 \%$ & $0 \%$ & $100 \%$ \\
\hline
\end{tabular}

Table 3: On the basis of Brand Promises

\begin{tabular}{|l|c|c|c|c|c|c|}
\hline & $\begin{array}{c}\text { Not } \\
\text { Satisfied }\end{array}$ & Dissatisfied & $\begin{array}{c}\text { Neither Satisfied nor } \\
\text { Dissatisfied }\end{array}$ & Satisfied & $\begin{array}{c}\text { Highly } \\
\text { satisfied }\end{array}$ & Total \\
\hline No. of users & 1 & 1 & 4 & 8 & 7 & 21 \\
\hline Percentage (\%) & $4.76 \%$ & $4.76 \%$ & $19.05 \%$ & $38.10 \%$ & $33.33 \%$ & $100 \%$ \\
\hline
\end{tabular}

Table 4: On the basis of Network coverage

\begin{tabular}{|l|c|c|c|c|c|c|}
\hline & Not Satisfied & Dissatisfied & $\begin{array}{c}\text { Neither Satisfied } \\
\text { nor Dissatisfied }\end{array}$ & Satisfied & $\begin{array}{c}\text { Highly } \\
\text { satisfied }\end{array}$ & Total \\
\hline No. of users & 0 & 0 & 1 & 18 & 2 & 21 \\
\hline Percentage (\%) & $0 \%$ & $0 \%$ & $4.76 \%$ & $85.71 \%$ & $9.52 \%$ & $100 \%$ \\
\hline
\end{tabular}

Table 5: On the basis of Price of internet package

\begin{tabular}{|l|c|c|c|c|c|c|}
\hline & Not Satisfied & Dissatisfied & $\begin{array}{c}\text { Neither Satisfied } \\
\text { nor Dissatisfied }\end{array}$ & Satisfied & $\begin{array}{c}\text { Highly } \\
\text { satisfied }\end{array}$ & Total \\
\hline No. of users & 1 & 0 & 2 & 16 & 2 & 21 \\
\hline Percentage (\%) & $4.76 \%$ & $0 \%$ & $9.52 \%$ & $76.19 \%$ & $9.52 \%$ & $100 \%$ \\
\hline
\end{tabular}


Table 6: On the basis of Bandwidth (Speed)

\begin{tabular}{|l|c|c|c|c|c|c|}
\hline & $\begin{array}{c}\text { Not } \\
\text { Satisfied }\end{array}$ & Dissatisfied & $\begin{array}{c}\text { Neither Satisfied } \\
\text { nor Dissatisfied }\end{array}$ & Satisfied & $\begin{array}{c}\text { Highly } \\
\text { satisfied }\end{array}$ & Total \\
\hline No. of users & 0 & 0 & 1 & 12 & 8 & 21 \\
\hline Percentage (\%) & $0 \%$ & $0 \%$ & $4.76 \%$ & $57.14 \%$ & $38.10 \%$ & $100 \%$ \\
\hline
\end{tabular}

Table 7: On the basis of Convenient bill payment

\begin{tabular}{|l|c|c|c|c|c|c|}
\hline & $\begin{array}{c}\text { Not } \\
\text { Satisfied }\end{array}$ & Dissatisfied & $\begin{array}{c}\text { Neither Satisfied } \\
\text { nor Dissatisfied }\end{array}$ & Satisfied & $\begin{array}{c}\text { Highly } \\
\text { satisfied }\end{array}$ & Total \\
\hline No. of users & 2 & 1 & 6 & 11 & 1 & 21 \\
\hline Percentage (\%) & $9.52 \%$ & $4.76 \%$ & $28.57 \%$ & $52.38 \%$ & $4.76 \%$ & $100 \%$ \\
\hline
\end{tabular}

Table 8: On the basis of Price of bundle pack

\begin{tabular}{|l|c|c|c|c|c|c|}
\hline & Not Satisfied & Dissatisfied & $\begin{array}{c}\text { Neither Satisfied } \\
\text { nor Dissatisfied }\end{array}$ & Satisfied & $\begin{array}{c}\text { Highly } \\
\text { satisfied }\end{array}$ & Total \\
\hline No. of users & 1 & 0 & 3 & 13 & 4 & 21 \\
\hline Percentage (\%) & $4.76 \%$ & $0 \%$ & $14.29 \%$ & $61.90 \%$ & $19.05 \%$ & $100 \%$ \\
\hline
\end{tabular}

Table 9: On the basis of Monthly cost/ Charge

\begin{tabular}{|l|c|c|c|c|c|c|}
\hline & Not Satisfied & Dissatisfied & $\begin{array}{c}\text { Neither Satisfied } \\
\text { nor Dissatisfied }\end{array}$ & Satisfied & $\begin{array}{c}\text { Highly } \\
\text { satisfied }\end{array}$ & Total \\
\hline No. of users & 2 & 3 & 9 & 6 & 1 & 21 \\
\hline Percentage (\%) & $9.52 \%$ & $14.29 \%$ & $42.86 \%$ & $28.57 \%$ & $4.76 \%$ & $100 \%$ \\
\hline
\end{tabular}

Table 10: On the basis of Welcome tune \& alert messages

\begin{tabular}{|l|c|c|c|c|c|c|}
\hline & Not Satisfied & Dissatisfied & $\begin{array}{c}\text { Neither Satisfied } \\
\text { nor Dissatisfied }\end{array}$ & Satisfied & $\begin{array}{c}\text { Highly } \\
\text { satisfied }\end{array}$ & Total \\
\hline No. of users & 4 & 3 & 10 & 4 & 0 & 21 \\
\hline Percentage (\%) & $19.05 \%$ & $14.29 \%$ & $47.62 \%$ & $19.05 \%$ & $0 \%$ & $100 \%$ \\
\hline
\end{tabular}

Table 11: On the basis of Price of SIM card \& value added services

\begin{tabular}{|l|c|c|c|c|c|c|}
\hline & $\begin{array}{c}\text { Not } \\
\text { Satisfied }\end{array}$ & Dissatisfied & $\begin{array}{c}\text { Neither Satisfied } \\
\text { nor Dissatisfied }\end{array}$ & Satisfied & $\begin{array}{c}\text { Highly } \\
\text { satisfied }\end{array}$ & Total \\
\hline No. of users & 1 & 0 & 6 & 9 & 5 & 21 \\
\hline Percentage (\%) & $4.76 \%$ & $0 \%$ & $28.57 \%$ & $42.86 \%$ & $23.81 \%$ & $100 \%$ \\
\hline
\end{tabular}

Table 12: On the basis of Helpful \& Prompt customer services

\begin{tabular}{|l|c|c|c|c|c|c|}
\hline & $\begin{array}{c}\text { Not } \\
\text { Satisfied }\end{array}$ & Dissatisfied & $\begin{array}{c}\text { Neither Satisfied } \\
\text { nor Dissatisfied }\end{array}$ & Satisfied & $\begin{array}{c}\text { Highly } \\
\text { satisfied }\end{array}$ & Total \\
\hline No. of users & 5 & 4 & 8 & 4 & 0 & 21 \\
\hline Percentage (\%) & $23.81 \%$ & $19.05 \%$ & $38.10 \%$ & $19.05 \%$ & $0 \%$ & $100 \%$ \\
\hline
\end{tabular}

Table 13: On the basis of Voice data plan

\begin{tabular}{|l|c|c|c|c|c|c|}
\hline & Not Satisfied & Dissatisfied & $\begin{array}{c}\text { Neither Satisfied } \\
\text { nor Dissatisfied }\end{array}$ & Satisfied & $\begin{array}{c}\text { Highly } \\
\text { satisfied }\end{array}$ & Total \\
\hline No. of users & 1 & 1 & 4 & 8 & 7 & 21 \\
\hline Percentage (\%) & $4.76 \%$ & $4.76 \%$ & $19.05 \%$ & $38.10 \%$ & $33.33 \%$ & $100 \%$ \\
\hline
\end{tabular}

Table 14: On the basis of Connection sharing facilities

\begin{tabular}{|l|c|c|c|c|c|c|}
\hline & $\begin{array}{c}\text { Not } \\
\text { Satisfied }\end{array}$ & Dissatisfied & $\begin{array}{c}\text { Neither Satisfied } \\
\text { nor Dissatisfied }\end{array}$ & Satisfied & $\begin{array}{c}\text { Highly } \\
\text { satisfied }\end{array}$ & Total \\
\hline No. of users & 5 & 1 & 7 & 8 & 0 & 21 \\
\hline Percentage (\%) & $23.81 \%$ & $4.76 \%$ & $33.33 \%$ & $38.10 \%$ & $0 \%$ & $100 \%$ \\
\hline
\end{tabular}

UniversePG I $\underline{\text { www.universepg.com }}$ 
Table 15: On the basis of Better and new product \& packages

\begin{tabular}{|l|l|c|c|c|c|c|}
\hline & $\begin{array}{l}\text { Not } \\
\text { Satisfied }\end{array}$ & Dissatisfied & $\begin{array}{l}\text { Neither Satisfied } \\
\text { nor Dissatisfied }\end{array}$ & Satisfied & $\begin{array}{l}\text { Highly } \\
\text { satisfied }\end{array}$ & Total \\
\hline No. of users & 1 & 0 & 6 & 13 & 1 & 21 \\
\hline Percentage (\%) & $4.76 \%$ & $0 \%$ & $28.57 \%$ & $61.90 \%$ & $4.76 \%$ & $100 \%$ \\
\hline
\end{tabular}

Table 16: On the basis of Overall services

\begin{tabular}{|l|c|c|c|c|c|c|}
\hline & Not Satisfied & Dissatisfied & $\begin{array}{l}\text { Neither Satisfied } \\
\text { nor Dissatisfied }\end{array}$ & Satisfied & $\begin{array}{l}\text { Highly } \\
\text { satisfied }\end{array}$ & Total \\
\hline No. of users & 3 & 0 & 6 & 10 & 2 & 21 \\
\hline Percentage (\%) & $14.29 \%$ & $0 \%$ & $28.57 \%$ & $47.62 \%$ & $9.52 \%$ & $100 \%$ \\
\hline
\end{tabular}

\subsection{Graphical Presentation}

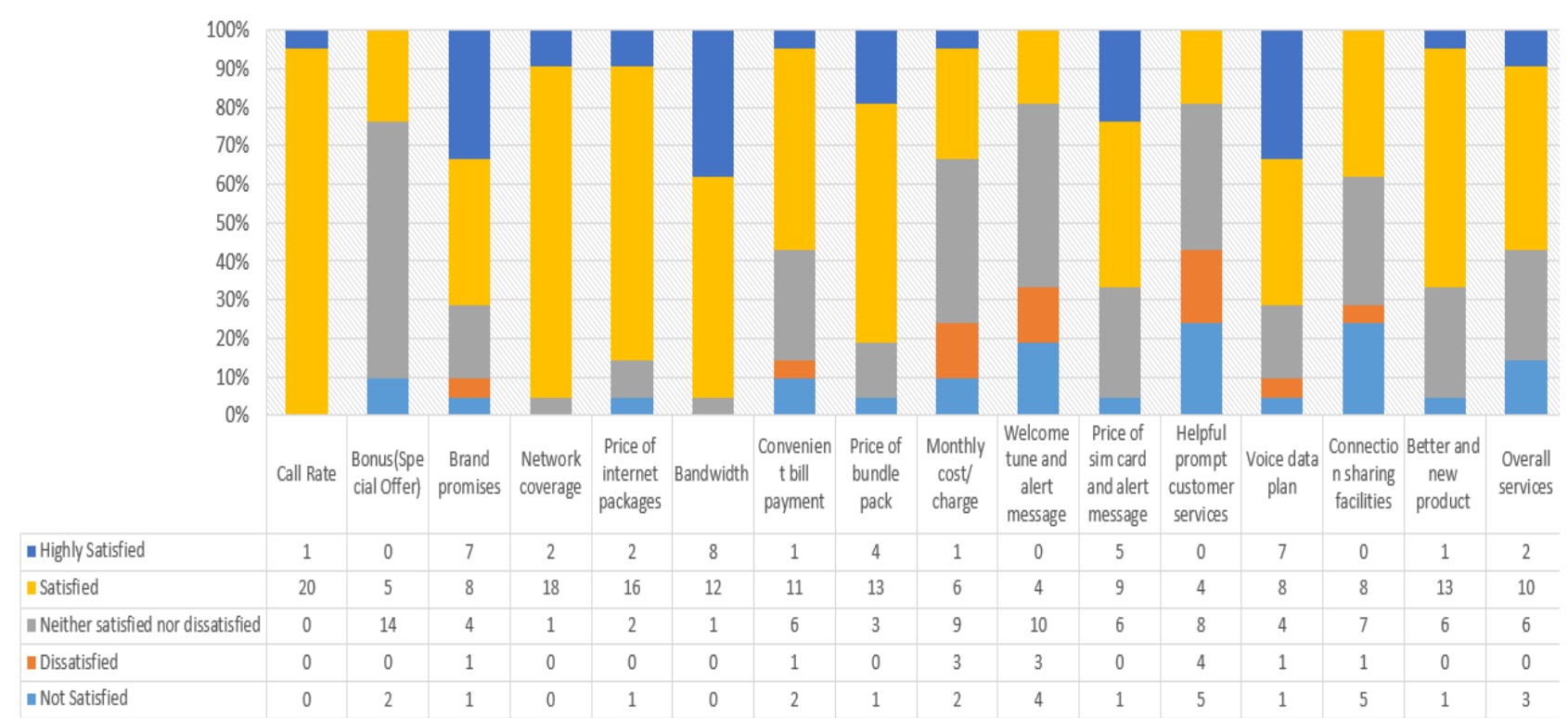

In the analysis it is originate that on the basis of call rate the satisfactions level is not satisfied $0 \%$, Dissatisfied $0 \%$, neither satisfied nor dissatisfied $0 \%$, Satisfied $95.24 \%$ and for highly satisfaction rate it is $4.76 \%$ (Table 1).

On the basis of Special offers (bonus) the extent of satisfactions are- not satisfied 9.25\%, Dissatisfied $0 \%$, neither satisfied nor dissatisfied $66.67 \%$, Satisfied $23.81 \%$ and for highly satisfaction rate it is $0 \%$ (Table 2).

On the basis of Brand promises the extent of satisfactions are- not satisfied 4.76\%, Dissatisfied 4.76\%, neither satisfied nor dissatisfied $19.05 \%$, Satisfied $38.10 \%$ and for highly satisfaction rate it is $33.33 \%$ (Table 3).

On the basis of Network coverage, the extent of satisfactions are not satisfied 0\%, Dissatisfied 0\%, neither satisfied nor dissatisfied $4.76 \%$, Satisfied $85.71 \%$ and for highly satisfaction rate it is $9.52 \%$ (Table 4).
On the basis of Price of internet packages, the extent of satisfactions is not satisfied $4.76 \%$, Dissatisfied $0 \%$, neither satisfied or dissatisfied $9.52 \%$, Satisfied $76.19 \%$ and for highly satisfaction rate it is $9.52 \%$ (Table 5).

On the basis of Bandwidth, the extent of satisfactions is not satisfied $0 \%$, Dissatisfied $0 \%$, neither satisfied or dissatisfied $4.76 \%$, Satisfied $57.14 \%$ and for highly satisfaction rate it is $38.10 \%$ (Table 6).

On the basis of convenient bill payment, the extent of satisfactions is not satisfied 9.52\%, Dissatisfied $4.76 \%$, neither satisfied nor dissatisfied $28.57 \%$, Satisfied $52.38 \%$ and for highly satisfaction rate it is $4.76 \%$ (Table 7).

On the basis of price of bundle pack the extent of satisfactions is not satisfied $4.76 \%$, Dissatisfied $0 \%$, neither satisfied or dissatisfied $14.29 \%$, Satisfied $61.90 \%$ and for highly satisfaction rate it is $19.05 \%$ (Table 8). 
Based on monthly cost/charge the extent of satisfactions are not satisfied 9.52\%, Dissatisfied $14.29 \%$, neither satisfied nor dissatisfied $42.86 \%$, Satisfied $28.57 \%$ and for highly satisfaction rate it is 4.76\% (Table 9).

Based on welcome tune and alert messages the extent of satisfactions is not satisfied $19.05 \%$, Dissatisfied $14.29 \%$, neither satisfied nor dissatisfied $47.62 \%$, Satisfied $19.05 \%$ and for highly satisfaction rate it is $0 \%$ (Table 10).

Based on price of SIM card and value-added services the extent of satisfactions is not satisfied 4.76\%, Dissatisfied $0 \%$, neither satisfied or dissatisfied $28.57 \%$, Satisfied $42.86 \%$ and for highly satisfaction rate it is $23.81 \%$ (Table 11).

Based on helpful and prompt customer care services the extent of satisfactions is not satisfied $23.81 \%$, Dissatisfied $19.05 \%$, neither satisfied nor dissatisfied $38.10 \%$, Satisfied $19.05 \%$ and for highly satisfaction rate it is $0 \%$ (Table 12).

Based on voice data pack, the extent of satisfactions is not satisfied $4.76 \%$, Dissatisfied $4.76 \%$, neither satisfied nor dissatisfied $19.05 \%$, Satisfied $38.10 \%$ and for highly satisfaction rate it is $33.33 \%$ (Table 13).

Based on connection sharing facilities, the extent of satisfactions is not satisfied $23.81 \%$, Dissatisfied $4.76 \%$, neither satisfied or dissatisfied $33.33 \%$, Satisfied $38.10 \%$ and for highly satisfaction rate it is 0\% (Table 14).

Based on better and new product \& packages, the extent of satisfactions is not satisfied $4.76 \%$, Dissatisfied $0 \%$, neither satisfied or dissatisfied $28.57 \%$, Satisfied $61.90 \%$ and for highly satisfaction rate it is $4.76 \%$ (Table 15).

Based on overall service, the extent of satisfactions is not satisfied $14.29 \%$, Dissatisfied 0\%, neither satisfied or dissatisfied $28.57 \%$, Satisfied $47.62 \%$ and for highly satisfaction rate it is $9.52 \%$ (Table 16).

\section{SWOT Analysis of Robi}

\section{Strength}

a) Publicity, Posturing, Sponsorship, etc. is the strong images of Robi. b) Offer useful products. Robi always maintenance an entrepreneur that's why they have unlike product for them named Uddokta \& Easy Load Tariff.

c) Robi is always using well equipment to give better facility to their customers. Now they are spending Nokia-Siemens instead of Alka-tell to deliver best superiority Network. Good relationship with retailer.

\section{Weakness}

a) Outside the Dhaka or sometimes inside the Dhaka lots of network problems are met by the client.

b) Poor network covering in the remote area so the result create dissatisfaction among the client.

c) Nonstop growths the using rate of mobile in Bangladesh that's why Robi has the chance to increase their customer base.

\section{Threats}

a) Limitation of Government regulations.

b) Five solid company limited are in Bangladesh, in this situation Robi has to tough hold their position.

c) So of the ferocity of the opponents and customers assembly Switching behavior, Robi is frequently reducing their market place segment. If it is keep going on, then it's very threatening for the business to exit.

\section{Opportunity}

a) Achieve the top position through employer brand.

b) Continues learning opportunity.

c) Business expansion opportunities.

d) Fund raising through new financial products.

e) Capital market operation.

f) Scope of product diversification.

\section{Findings}

The key findings are:

- Call rate, coverage of network, network quality, internet, tariff, customer care, value added services, bill payment system, advertising offers are the most important factors that affect customer satisfaction.

- Clients are more satisfied with Internet service of Robi. 
- Bad network quality to the remote area to the comparison with Dhaka city.

- Average income of Subscriber life sequence is all most equivalent to the SIM tax. As a result, it develops very tough to take out profit from the operation.

\section{CONCLUSION:}

In this new era of modern world nobody cannot think without telecommunication. On behalf of technology the world is to very shorter. In Bangladesh the telecommunication was launched in 1993, after 26 years the total amount of user near about 7 cores. There are four notable mobile companies in Bangladesh right now and they are fighting to one another. So, if Robi Company intends to control the market. It surely reflects the happiness level of the client. It must need to sweet able offer to the customer, without this it must reflect on the market therefore they will continue in the market place (Mezgebe, 2020). Should be remained on the customer desire and demand. To understand objective of this paper has been shown in order tough it out the issues which mostly effect the customer gratification along with its gratification level. From time-to-time user demand varies so, telecommunication operator should concentrate on user demand and how they are pleased. Here some important issues have been acknowledged that contribute highly in overall customer satisfaction. These issues that have been acknowledged are of excessive rank to mobile facilities benefactor and to customers along with. The operators can also advantage from these issues as it will confirm client gratification and faithfulness which will get cash from them. It can be determined that this research will aid the mobile operator to recover their facilities in this arena in which they are worried.

\section{Recommendation}

Depend on finding, here are around recommenddations for that telecom company:

- Before starting any recent package, they should study these issues extremely. Because to fulfill the basic needs or wants of a customer.

- Operators can decrease customer charge and provide rise value by plummeting tariff and growth smaller pulse.

- To familiarize a latest service.
- The mobile operatives should intensify the network coverage and surely reflecton the quality.

- Customer's impression is significant to develop the company so try to spend more time on corporate social job responsibilities.

- Try to launch advanced level technology like $5 \mathrm{G}$ to gain better support for broad band and quality network.

\section{ACKNOWLEDGEMENT:}

The researcher specially thanks to his mentor Md. Mahbubul Islam, associate professor, department of Information Science and Library Management, University of Rajshahi for his special guidelines with his appreciated time, co-ordination and always for mentoring. This would not complete without his help like as reading of draft as many times.

\section{CONFLICTS OF INTEREST:}

The researcher is clearly declared that there is no possible of conflict of interest about the study, with the data collection along with analysis of the data as well as authorship and publication of his present article.

\section{REFERENCES:}

1) Al Jamil, A., Sunny, S. H., \& Hasan, R. (2015). Factors Influencing the Behavior of the Mobile Phone Users to Switch their Mobile Telecommunication Operators in Bangladesh. International Journal of Trade \& Commerce-IIARTC, 4.

2) Chen, J. C., Patten, D. M., \& Roberts, R. W. (2008). Corporate charitable contributions: a corporate social performance or legitimacy strategy? Journal of Business Ethics, 82(1), 131-144.

https://www.jstor.org/stable/25482278?seq=1

3) Gereziher B. and Shiferaw Y. (2020). Corporate social responsibility practice of multinational companies in Ethiopia: a case study of Heineken Brewery S.C, Br. J. Arts Humanit., 2(2), 36-55. https://doi.org/10.34104/bjah.020036055

4) Hossain MR, Khatun S, and Rashid MA. (2019). Present status of information and internet services in union council of Madhu- 
khali upazila: a case study, Br. J. Arts Humanit., 1(6), 35-44. https://doi.org/10.34104/bjah.019.35044

5) Jony MTI, Alam MJ, and Rana MS. (2019). Customers' satisfaction of service quality: a study on the customers of DBBL at different areas of Mymensingh district. Can. J. Bus. Inf. Stud., 1(5), 10-16. https://doi.org/10.34104/cjbis.019.01016

6) Kim, D. I., Matsuyama, Y., Nagasoe, S., \& Honjo, T. (2004). Effects of temperature, salinity and irradiance on the growth of the harmful red tide dinoflagellate Cochlodinium polykrikoides margalef (Dinophyceae). Journal of Plankton Research, 26(1), 61-66. https://doi.org/10.1093/plankt/fbh001

7) Li, Y., Qi, J., \& Shu, H. (2008). A study on customer satisfaction in mobile telecommunication market by using SEM and system dynamic method. In Research and Practical Issues of Enterprise Information Systems II (pp. 1221-1226). Springer, Boston, MA. https://doi.org/10.1007/978-0-387-76312-5_48

8) Mezgebe A. (2020). Effect of electronic marketing on customer satisfaction: the case of four star hotels in Addis Ababa, Int. J. Manag. Account. 2(4), 74-95. https://doi.org/10.34104/ijma.020.074095

9) Pizam, A., Shapoval, V., \& Ellis, T. (2016). Customer satisfaction and its measurement in hospitality enterprises: a revisit and up- date. International Journal of Contemporary Hospitality Management, 28(1):2-35. https://doi.org/10.1108/IJCHM-04-2015-0167

10) Rahman, H. (2014). Factors affecting customer satisfaction in mobile telecommunication industry in Bangladesh. Business, Management and Education, 12(1), 74-93. https://doi.org/10.3846/bme.2014.06

11) Saha, N., Islam, M., \& Hoque, A. (2016). Factors affecting customers' satisfaction of mobile phone subscribers: an empirical study on mobile telecommunication Industry in Bangladesh. International Journal of Business and Management, 11(6), 252. https://doi.org/10.5539/ijbm.v11n6p252

12) Shuvro RA, Saha S, and Alam MJ. (2020). Measuring the level of job satisfaction of the employees of Grameen bank: an empirical study, Can. J. Bus. Inf. Stud., 2(1), 1-11. https://doi.org/10.34104/cjbis.020.01011

13) Smith, A. K., Bolton, R. N., \& Wagner, J. (1999). A model of customer satisfaction with service encounters involving failure and recovery. J. of marketing research, 36(3), 356-372. https://doi.org/10.2307/3152082

14) Uddin, M. B., \& Akhter, B. (2012). Customer satisfaction in mobile phone services in Bangladesh: A survey research. Management \& Marketing Journal, 10(1), 20-36. http://www.mnmk.ro/documents/2012-first/2 15_1_12_FFF.pdf

Citation: Khatun S, and Hossain MR. (2021). Customer's satisfaction toward Robi Axiata Limited: study on Rajshahi University area, Br. J. Arts Humanit., 3(2), 48-55. https://doi.org/10.34104/bjah.021048055 @) () 